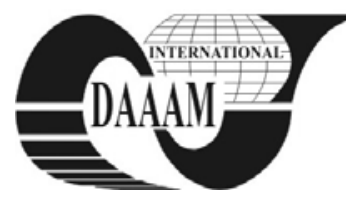

\title{
ASPECTS REGARDING THE ROLE OF HIGHER EDUCATION AND PROFESSIONAL TRAINING IN THE GROWTH OF ECONOMIC COMPETITIVENESS IN ROMANIA IN THE OTHER EUROPEAN UNION COUNTRIES
}

\author{
TANASE, A[drian] C[ostinel] \& TANASE, F[lorenta] D[iana]
}

\begin{abstract}
Considering the complexity of the theme, the study of the role of the educational system on the increase of economic competitiveness represents a topic to be analysed with great attention. In these circumstances, one should understand that the essence of the idea of human capital refers to the investments in human resources, with the purpose of increasing labour productiveness.
\end{abstract}

Key words: competitiveness, performance, education, human capital

\section{INTRODUCTION}

The issue of economic competitiveness is constantly found on the past years' public agenda. Competitiveness is a complex concept, at length debated at present by economist and politicians worldwide, by the media and even the ordinary citizens.

As shown in numerous economic studies (such as those elaborated by the European Institute of Romania, International Institute for Management Development, World Economic Forum, World Travel and Tourism Council, Eurostat etc.), a series of factors act on the economic competitiveness, among which higher education and professional training play an important part.

The quality of higher education and professional training is essential for the economies intending to take the value chain beyond the mere manufacturing processes. The globalisation of today's economy especially requires countries to prepare welltrained workers able to rapidly adapt to the environment changes (World Economic Forum, 2011).

The stock of human capital existing at a certain moment constitutes an important factor of growth and economic-social development, the proof being the development of macroeconomic research focused on the integration of education into the manufacture function, used in the study of economic growth.

Whereas the increase of investments triggers the increase of the economy's physical capital stock, the educational system lies at the basis of the human capital growth (Stiglitz \& Walsh, 2005).

Consequently, the quality of training and the acquisition of new abilities by the labour force become more and more important at present, as factors of competitiveness.

The paper approaches thus a topic of present utmost interest, rising the interest of specialists, governance, media and, last but not least, the interest of entrepreneurs, irrespective of their domain of activity.

\section{HIGHER EDUCATION AND PROFESSIONAL TRAINING IN ROMANIA AND THE OTHER EUROPEAN UNION COUNTRIES}

It was established that the countries with a population with high level of education and professional training are the most productive from the economic viewpoint, real data showing that the percentage of engineers and scientists in the total labour force represents a determining factor of rapid economic growth (Stiglitz \& Walsh, 2005).

Unfortunately, higher education and professional training represent an aspect where Romania registered significant gaps compared to most European Union countries (table 1).

\begin{tabular}{|l|c|c|}
\hline \multirow{2}{*}{ Country } & \multicolumn{2}{|c|}{$\begin{array}{c}\text { Higher education and professional } \\
\text { training }\end{array}$} \\
\cline { 2 - 3 } & Rank & Points \\
\hline Finland & & 6.06 \\
\hline Sweden & 2 & 5.90 \\
\hline Denmark & 3 & 5.84 \\
\hline Belgium & 4 & 5.71 \\
\hline Netherlands & 5 & 5.63 \\
\hline Austria & 6 & 5.38 \\
\hline France & 7 & 5.36 \\
\hline Great Britain & 8 & 5.34 \\
\hline Germany & 9 & 5.33 \\
\hline Slovenia & 10 & 5.27 \\
\hline Estonia & 11 & 5.17 \\
\hline Ireland & 12 & 5.17 \\
\hline Czech Republic & 13 & 5.11 \\
\hline Lithuania & 14 & 5.07 \\
\hline Poland & 15 & 5.00 \\
\hline Cyprus & 16 & 4.91 \\
\hline Spain & 17 & 4.85 \\
\hline Hungary & 18 & 4.81 \\
\hline Latvia & 19 & 4.81 \\
\hline Malta & 20 & 4.79 \\
\hline Portugal & 21 & 4.76 \\
\hline Luxembourg & 22 & 4.68 \\
\hline Greece & 23 & 4.67 \\
\hline Italy & 24 & 4.60 \\
\hline Slovakia & 25 & 4.49 \\
\hline Romania & 26 & 4.47 \\
\hline Bulgaria & 27 & 4.14 \\
\hline
\end{tabular}

Tab. 1. Higher education and professional training - Index of competitiveness at the level of the European Union

Source: Elaborated by the authors based on the World Economic Forum data, The Global Competitiveness Report 2010 - 2011, pp. 20-21.

Remark: The ranking is made depending on the performances of the educational system in these countries (including the activities of professional training), the evaluation being made on a scale from 1 to 7 , where 1 represents the worst situation, whereas 7 represents the best situation.

In the year 2007, at the level of the European Union there were 18.9 million students, and countries such as Great Britain, Germany, France, Poland, and Italy had over 2 million of studies. These five countries, together with Spain, represented over two thirds of the total of European Union students.

Finland, Denmark, Sweden are still in top position as regards higher education and the professional training criterion, a positive result of the strong accent on education they have 
laid in the last decades. This provided the labour force with a series of competencies necessary for rapidly adapting to an environment in constant change and put the bases of high adoption levels of new technologies and innovation.

Whereas in the European Union in 2008 only one quarter of the population aged between 25 and 64 had higher education, in Finland, Denmark, Cyprus and Estonia the proportion of persons with higher education represented more than a third. In contrast, in Slovakia, Czech Republic, Italy, Portugal, Malta and Romania, less than $15 \%$ of the population aged between 25 and 64 had academic training (Eurostat, 2010).

In fact, according to the Romanian Institute of Statistics, in the Northern countries (ranked on the three top positions in the competitiveness ranking depending on higher education and professional training), the gross rate of school enrolment in higher education was, in 2008-2009, the highest in the European Union: Finland (94\%), Denmark (80\%), Sweden (71\%). In Romania, although the number of students has increased almost three times in the past 16 years, the gross rate of school enrolment in higher education was only $55 \%$ in 2008 2009 (ARACIS, 2010). On the other hand, considering that the number of students has increased very much in these past years "the population of the teaching staff in higher education has a sub-proportional or much slower growth rate" which affects the educational services, whose quality is diminished.

Obviously, beyond the quantitative dimension, a crucial role in the development of labour force is played by the quality of higher education.

In these circumstances, the reforms regarding the school curricula promoted by the Bologna process aimed at creating a European higher education domain facilitating the mobility of students, transparency and recognition of qualifications, promoting at the same time a European dimension of higher education, keeping in mind that some European universities are among the best in the world.

As for lifelong learning, according to an Eurostat survey (Eurostat, 2010), in 2008, in the European Union, the percentage of persons aged between 25 and 64 who benefited from lifelong learning was of $9.6 \%$, this results being only by $1.1 \%$ higher than the results of a similar survey performed in 2003. The percentage of the population having participated in lifelong learning activities was higher among women $(10.4 \%$ in 2008), while in the case of men it reached only $8.7 \%$. The countries where the highest percentages were recorded were Sweden, Denmark, Great Britain and to a certain extent Finland (ranging from $20 \%$ to $33 \%$ ). At the opposite pole, the lowest rates of participants in lifelong learning were found in Bulgaria and Romania (less than 2\%). Moreover, in Romania the trend of the training supply is to focus on programmes for general skills (computer use, foreign languages, accounting, etc.) and less on specific skills.

Consequently, lifelong learning represents an essential element for the development of the knowledge-based society, considered to be the main driving engine for competitive development (Cojanu et al., 2007).

Nevertheless, the development of human capital is achieved not only by school education, by investments in health, but also by the professional training at the place of work, because, like the physical capital, the human capital risks as well to undergo a "depreciation" (Macmillan Dictionary, 1999).

Regarding the lifelong professional training at the place of work, in 2005 (the last year for which Eurostat presents data on this topic), in Romania only $40 \%$ of the total enterprises organised such courses of training, lesser percentages being registered in Greece (21\%), Bulgaria (29\%), Italy (32\%), Latvia (36\%) and Poland (35\%). Moreover, one should pay attention to the very high percentage of companies having organised courses of lifelong professional training at the place of work in the United Kingdom (90\%), Sweden (78\%), Finland (77\%), Denmark (85\%), Austria (81\%).
On the other hand, as regards the average time spent in attending such training courses (hours/employee), in 2005, the Romanian companies had 5 hours/employee, far below the average of northern countries, between 10 and 15 hours/employee.

The amounts invested in professional training generate the increase of human capital quality, considered to be an active and dynamic source of competitiveness growth.

Professional training constitutes an instrument facilitating the transition towards a sustainable world and the optimum use of human resources, the training programmes aiming at promoting the development issues.

In Denmark, the percentage of expenditure for lifelong professional training in the total cost of labour force was of $3 \%$ (the higher in the Union), in Belgium, the Czech Republic, Estonia, Ireland, France, Luxembourg, Hungary, Malta, The Netherlands, Slovenia, Slovakia, Finland and Sweden this expenditure represented $2 \%$, whereas in Romania, the expenditure for the lifelong professional training in the total cost of labour force was of $1 \%$, the same percentage being recorded in other countries also, such as Germany, Spain, Italy, Austria (Eurostat, 2010). Obviously, although we talk about the same percentage, as the labour force cost is much lower in our country compared to the others, the absolute value of the expenditure for professional training is much smaller in Romania compared to Germany, Austria, Spain or Italy.

\section{CONCLUSION}

Numerous studies reflect the close connection between the qualification level of human capital and economic growth, as well as the direct and indirect impact on the economic system, the operation of a modern economy requiring the existence of a well-trained labour force.

Education, public awareness and training represent a process in which the human capital may reach its maximum potential. The personnel's training degree (an issue neglected in many economies) is taken into consideration in the analysis of a nation's competitiveness level, as the professional training at the place of work assures the constant growth of employees' competence, as well as their adaptation to the constantly changing economy needs.

Stimulating the preparation of a flexible well-trained labour force (with accent on lifelong learning and higher education) and well-paid at the same time, should constitute one of the priority goals of Romania, in accordance with the objectives of the UE 2020 Strategy.

\section{REFERENCES}

Cojanu, V.; Bîrsan, M.; Unguru, M. (2007). Competitiveness of Romanian economy: adjustments necessary for reaching the Lisbon Agenda objectives, European Institute of Romania, pg. 46, ISBN 978-973-7736-40-6, Bucharest

Stiglitz, J.; Walsh C. (2005). Economy, Economic Editions, pp. 539-542, ISBN 973-590-822-0, Bucharest

*** Eurostat, Europe in figures - Eurostat yearbook 2010, pp. 262-277

*** (1999) Macmillan Dictionary of modern economics, Codecs Editions, pg. 49, ISBN 973-98491-4-8, Bucharest

*** (2010) National Institute of Statistics, Romania's Statistic Yearbook, pg. 707

*** (2010) Romanian Agency for Quality Assurance in Higher Education (ARACIS), Quality barometer - 2009. Statistic distributions, interpretations and options regarding the quality state in higher education, pg. 87, Bucharest

*** World Economic Forum, The Global Competitiveness Report, 2010 - 2011, pp. 5-23 